\title{
36. SHALLOW BURIAL DIAGENESIS OF CHALKS AND RELATED SEDIMENTS AT SITE 550 ON THE GOBAN SPUR ${ }^{1}$
}

\author{
Robert H. Jennings and Jim M. Mazzullo, Department of Geology, Texas A\&M University²
}

\begin{abstract}
Leg 80 of the Deep Sea Drilling Project drilled four coreholes through syn- and postrift sediments on the seaward edge of the Goban Spur in the Bay of Biscay. A relatively thin sedimentary veneer composed of nannofossil chalk and calcareous and siliceous mudstone was cored, providing the opportunity to document the effects of burial depth and other factors on the porosity of chalks by means of the scanning electron microscope. Four diagenetic "facies" were described from SEM analysis of the chalks; in order of increasing depth they are (1) mechanical compaction facies, (2) a transitional facies with both mechanical and chemical compaction features, (3) a chemical compaction facies, and (4) a cement-inhibited facies. It appears that advanced stages of cementation and lithification can occur in pure chalks at relatively shallow depths of burial $(100-700 \mathrm{~m})$ but can be inhibited by the presence of clays and coarser grained detritus.
\end{abstract}

\section{INTRODUCTION}

In recent years much research has focused on the lithology, lithification, and diagenesis of chalks. This research has been accomplished largely through the work of the Deep Sea Drilling Project and by the work of petroleum exploration geologists in deeply buried marine sediment.

Chalks are composed primarily of the disaggregated remains of coccospheres, a golden brown algae belonging to the nannofossil group, and can be classified as a micritic limestone. Chalks typically have a high chemical stability as compared with other limestones, because most of the carbonate particles are composed of lowmagnesium calcite. Coccolith shield diameter usually ranges from 1 to $20 \mu \mathrm{m}$, which results in relatively low permeabilities in chalk deposits. Upon initial deposition, however, the porosity in chalks may be as high as 70 or $80 \%$, making these deposits potentially suitable as reservoir rocks for hydrocarbons. Reduction in chalk porosity in response to diagenesis can produce porosities that range from $50 \%$ to as low as $1 \%$. The extreme range in potential porosity reduction in response to diagenesis and lithification is dependent on the complex interplay of the diagenetic mechanisms at work and the lithologic properties of the chalk itself.

The major processes at work in burial diagenesis are mechanical and chemical compaction (solution transfer of Scholle, 1977). Some of the features associated with mechanical compaction are compactional dewatering, grain breakage, grain reorientation, and grain repacking. The major processes involved in chemical compaction are pressure solution (characterized by bulk volume reduction), spot welding, dissolution, and reprecipitation.

As a result of pressure solution, minerals under stress dissolve at crystal contacts where pressure is greatest.

\footnotetext{
${ }^{1}$ Graciansky, P. C. de, Poag, C. W., et al., Init. Repts. DSDP, 80: Washington (U.S. Govt, Printing Office).

Address: Department of Geology, Texas A\&M University, College Station, TX 77843.
}

The calcium carbonate that has dissolved usually migrates to an area of lower pressure that is normally close to the site of active dissolution, where it precipitates either on part of a coccolith, creating an overgrowth, or in the pore space between coccolith fragments. If pressure solution is the source of pore-filling cement, then a large degree of bulk volume reduction must accompany the dissolution process in the sediment, thereby effectively reducing porosity (Manus and Cougan, 1974).

There are several lithologic properties of the chalk itself that interact to control the relative rate and onset of chemical compaction in burial diagenesis, such as variation in coccolith morphology, chemical stability of skeletal material, and clay content. Depth of burial, however, is considered by some researchers (Fischer et al., 1969; Scholle, 1977) to be the only major factor that consistently correlates with regional porosity loss in chalks. They consider that above a burial depth of 250 to $300 \mathrm{~m}$, only mechanical compaction serves to reduce chalk porosity, whereas major chemical compaction as a response to lithostatic loading occurs only below $1000 \mathrm{~m}$.

This study examines the diagenesis of a section of chalky sediments drilled by Leg 80 of the Deep Sea Drilling Project on the sediment-starved Goban Spur; the site under examination, 550 (Fig. 1), was drilled $10 \mathrm{~km}$ southwest of the seaward edge of the Spur. The Goban Spur itself is part of a starved, passive continental margin where synrift sedimentation was initiated in Early Cretaceous time. The tectonic setting is characterized by a series of tilted blocks bounded by listric faults that have been covered by a relatively thin veneer of nearly flatlying, postrift sediments (Montadert and Roberts, 1977). Approximately $720 \mathrm{~m}$ of lower Pliocene to upper Albian nannofossil chalk, marly chalk, and calcareous and siliceous mudstone overlying basaltic basement were cored at this site.

The purpose of this study is to describe the diagenetic alteration of pure nannofossil chalk and related sediment at burial depths of less than $700 \mathrm{~m}$. It will also test the prevailing assumption that for most chalks, cementation is a significant factor in porosity reduction only 


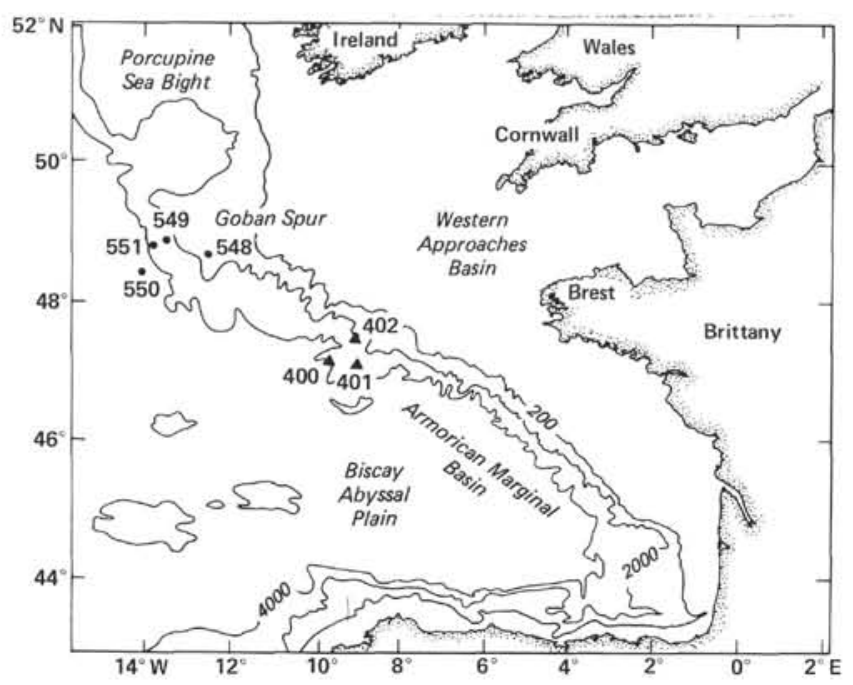

Figure 1. Physiography of Bay of Biscay and vicinity, showing the location of the Goban Spur where Site 550 and others were drilled.

at burial depths greater than $1000 \mathrm{~m}$. The relationship between chalk lithology and the degree of chalk lithification will also be examined.

\section{SAMPLES AND METHODS}

Chalk and related sediment cored at Site 550 of the Deep Sea Drilling Project were used in this study to document diagenetic features occurring at relatively shallow depths of burial. Chalks from Site 550 were sampled at eight intervals (Table 1). Chemical analyses showed a calcium carbonate composition of greater than $77 \%$, and smear slides indicated a predominance of clay- and silt-sized fragments. Two samples ( 9 and 10) from sections with relatively high contents of clay and coarse skeletal debris were also studied in an attempt to ascertain any relationship between the presence of these components and the occurrence of certain diagenetic features.

Each sample was mounted on an aluminum stub and dried at $100^{\circ} \mathrm{F}$ for $24 \mathrm{hr}$. to remove any moisture present in pores. They were then coated with a thin layer of a gold-palladium alloy to insure proper conductivity while subjected to the electron beam of the SEM. A
JEOL-25S Scanning Electron Microscope in the Electron Microscopy Center at Texas A\&M University was used to observe and document the stages of diagenesis occurring in the samples.

\section{RESULTS}

Figure 2A shows the morphology of undeformed coccoliths that are unlithified and have relatively high (60-70\%) intergranular porosities. Figures 2B, C, and $\mathrm{D}$ show various aspects of mechanical compaction that have occurred in the core at burial depths less than $300 \mathrm{~m}$. In Sample 1 (Fig. 2B), compactional dewatering has driven out most of the interstitial fluid between grains, leaving a field of relatively intact coccoliths in various orientations with few fragmentary elements resulting from mechanical breakage and reorientation. In Sample 2, mechanical compaction is extensive, resulting in a large number of individual calcite laths, broken coccolith shields, and an oriented grain fabric (Fig. 2C). Also present in this sample is one undamaged coccosphere that has resisted compactive stress and exhibits typical coccolithophore morphology prior to disarticulation.

Coccolith fragments from Sample 3 (Fig. 2D) show some rounded edges and spot welding to other crystal elements, demonstrating the onset of early dissolution and cementation at a shallow depth of burial (about $300 \mathrm{~m}$ ). Although no cement overgrowths are readily apparent, dissolution has begun to occur, and porosity is already drastically reduced. At this depth mechanical compaction has reached a maximum, and the processes associated with chemical compaction have commenced.

Features showing the transition from mechanical to chemical compaction are illustrated in Figure 3. Sample 4 , taken at a depth of 355 (Fig. 3A), shows various coccolith elements having rounded outlines, which is evidence of dissolution, in addition to some minor overgrowth formation in the center of the coccolith shields. Much of the matrix has a welded, massive texture, showing the effects of early cementation. Well-developed cal-

Table 1. Sample location, age, and description, showing diagenetic changes with depth, Site 550 .

\begin{tabular}{|c|c|c|c|c|}
\hline $\begin{array}{l}\text { Sample } \\
\text { number }\end{array}$ & Sample & $\begin{array}{l}\text { Depth BSFa } \\
\text { (m) }\end{array}$ & $\begin{array}{l}\text { Geologic } \\
\text { age }\end{array}$ & Description of diagenetic features and porosity \\
\hline \multicolumn{5}{|c|}{ Hole 550A } \\
\hline 1 & $2-1,55-58 \mathrm{~cm}$ & $100-110$ & early Pliocene & $\begin{array}{l}\text { Disarticulated coccospheres; some mechanical com- } \\
\text { paction and fragmentation of coccoliths }\end{array}$ \\
\hline 2 & $11-2,100-102 \mathrm{~cm}$ & $185-195$ & late Miocene & $\begin{array}{l}\text { More intense mechanical compaction, fragmentation, } \\
\text { and formation of a larger number of broken } \\
\text { coccoliths; reduction of pore space }\end{array}$ \\
\hline 3 & $19-2,67-71 \mathrm{~cm}$ & $260-270$ & middle Miocene & $\begin{array}{l}\text { Coccolith fragments and coccoliths in equal amounts; } \\
\text { some dissolution of individual calcite laths }\end{array}$ \\
\hline 4 & $29-4,41-44 \mathrm{~cm}$ & $355-365$ & early Eocene & $\begin{array}{l}\text { Fragmented coccoliths, more dissolution of coccolith } \\
\text { shields; some early cement, reduced porosity }\end{array}$ \\
\hline 5 & $37-1,64-66 \mathrm{~cm}$ & $432-442$ & late Paleocene & $\begin{array}{l}\text { Dissolution and cementation evident; some recrystal- } \\
\text { lization of calcite; overgrowths present }\end{array}$ \\
\hline \multicolumn{5}{|c|}{ Hole 550B } \\
\hline 6 & $2-2,127-129 \mathrm{~cm}$ & $470-480$ & Campanian & $\begin{array}{l}\text { Extensive calcite overgrowth, cement; intense chemi- } \\
\text { cal compaction, crystallization }\end{array}$ \\
\hline 7 & $8-1,123-125 \mathrm{~cm}$ & $524-534$ & Maestrichtian & $\begin{array}{l}\text { Extensive overgrowths, reprecipitation features; com- } \\
\text { plete coccolith dissolution; low porosity }\end{array}$ \\
\hline 8 & $13-1,1-2 \mathrm{~cm}$ & $569-579$ & $\begin{array}{l}\text { Santonian or } \\
\text { Coniacian }\end{array}$ & $\begin{array}{l}\text { Large areas of overgrowth, calcite cement; welded } \\
\text { texture; a few porous zones }\end{array}$ \\
\hline 9 & $15-5,85-89 \mathrm{~cm}$ & $588-598$ & $\begin{array}{l}\text { middle Ceno- } \\
\text { manian }\end{array}$ & $\begin{array}{l}\text { Minor overgrowths and spot welding, moderate } \\
\text { porosity; scarce patchy cement; clays present }\end{array}$ \\
\hline 10 & $25-3,38-40 \mathrm{~cm}$ & $680-686$ & late Albian & $\begin{array}{l}\text { Moderate porosity, some spot welding and pressure } \\
\text { solution; not much cementation; clays present }\end{array}$ \\
\hline
\end{tabular}

${ }^{\text {a }}$ BSF $=$ below seafloor. 

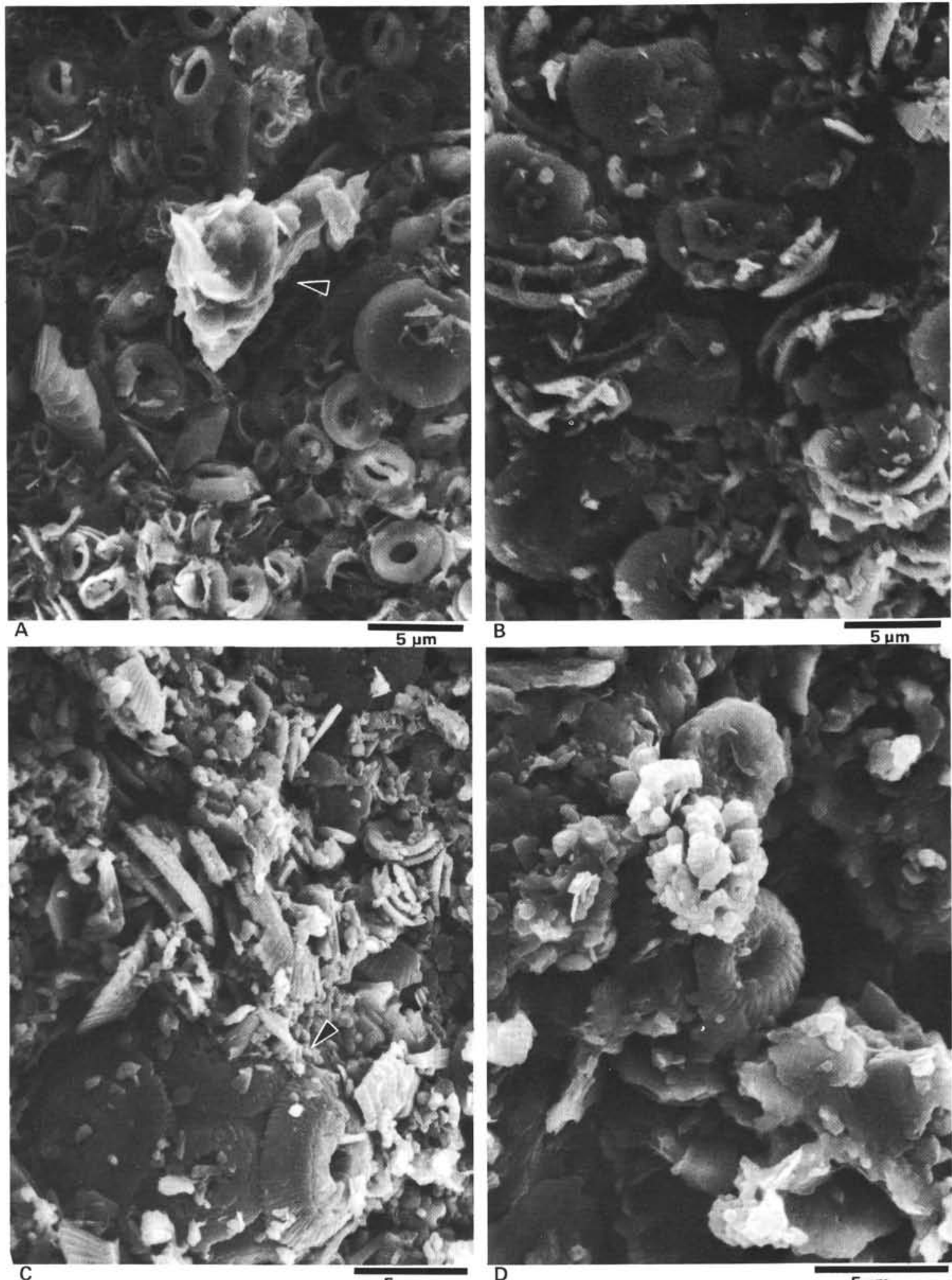

$5 \mathrm{um}$

5 um

Figure 2 . SEM photomicrographs, $\times 3000$, of chalk Samples 1,2 , and 3 showing features associated with mechanical compaction and incipient chemical compaction at shallow depths of burial. A. Holocene coccoliths from just below the seafloor showing relatively intact, undeformed disarticulated coccospheres. Feature in center of micrograph (arrow) is clay rosette. B. Coccoliths from Sample 1; relatively intact with some evidence of mechanical compaction resulting in fragmentation of coccoliths and dewatering. Depth $=100-110 \mathrm{~m}$. C. Numerous coccoliths, coccolith fragments, and one uncommon intact coccosphere from Sample 2. Mechanical compaction is intense, resulting in a large number of partial shields and individual calcite laths. Coccosphere in lower part of micrograph (arrow). Also note the slightly oriented fabric of the sediment. Depth $=185-195 \mathrm{~m}$. D. Coccoliths from Sample 3, showing increased intensity of mechanical compaction and probable initiation of dissolution of fragmented coccoliths. Edges of shields and calcite laths appear to be rounded, and early cementation may have occurred, creating spot welding features. Depth $=260-270 \mathrm{~m}$. 

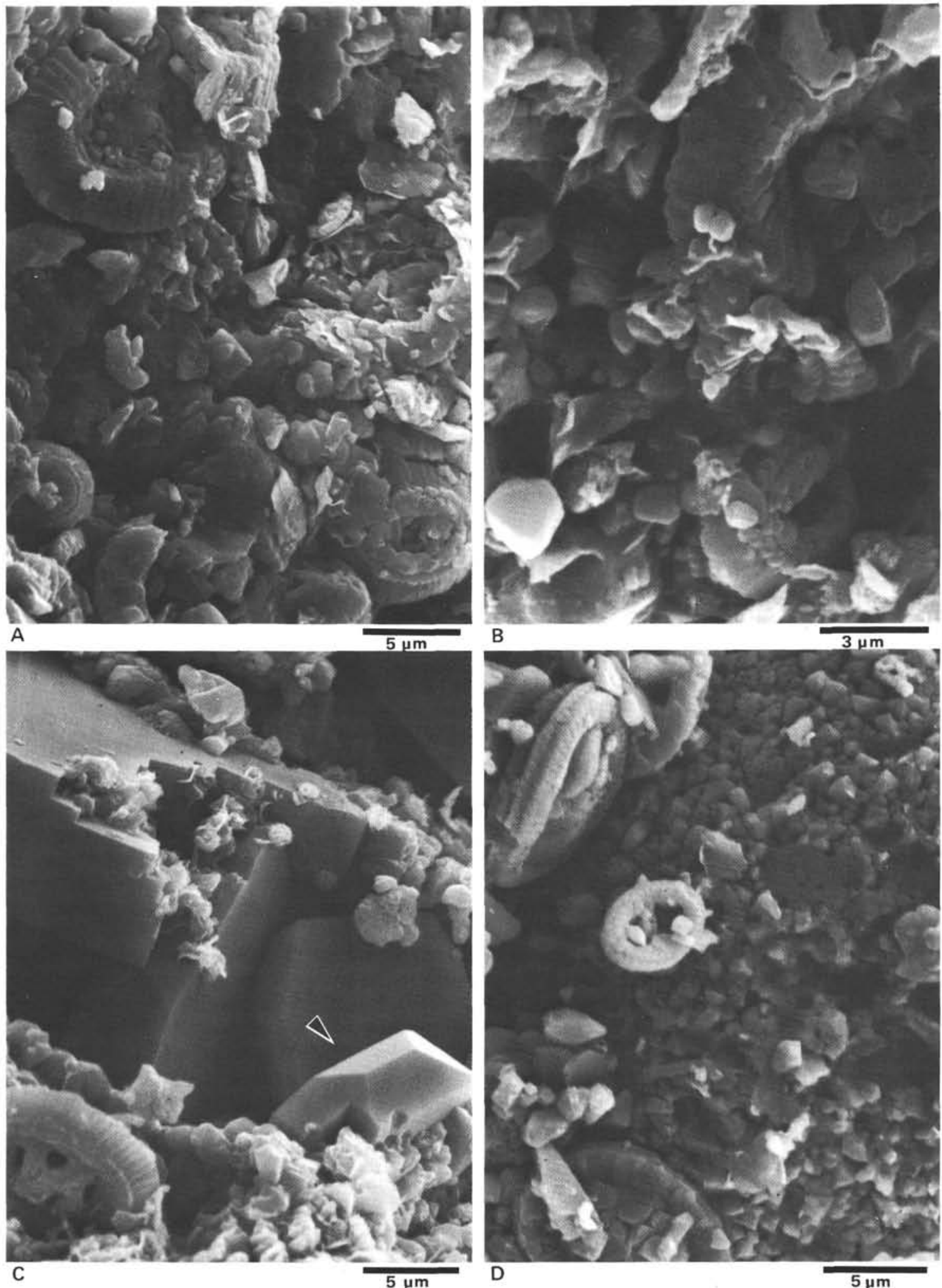

Figure 3. SEM photomicrographs of chalk Samples 4, 5, and 6 showing advanced stages of mechanical compaction and initiation of chemical compaction with dissolution and overgrowth features. A. Coccoliths from Sample 4, showing more apparent dissolution features with well-rounded calcite laths, $\times 3000$. Cementation in the form of welding is evident. Depth $=355-365 \mathrm{~m}$. B. Coccoliths from Sample 5 showing rounded coccolith fragments as evidence of dissolution, $\times 7000$. Some overgrowth formation has also occurred, giving calcite laths a block, irregular outline. Depth $=432-442 \mathrm{~m}$. C. Coccoliths and calcite cementation from Sample 5, $\times 3000$. Chemical compaction in the form of dissolution and reprecipitation of coccolith shields has resulted in well-developed crystals of calcite cement (arrow). Cementation appears to have occurred in multiple stages because of secondary mineralization occurring on calcite crystals after their formation. Depth $=432-442 \mathrm{~m}$. D. Coccoliths and extensive cementation and overgrowths from Sample 6, $\times 3000$. Chemical compaction is at advanced stage and porosity is drastically reduced. Mechanical compaction processes have apparently been replaced by chemical compaction. Depth $=470-480 \mathrm{~m}$. 
cite crystals in Sample 5 (Figs. 3B and C) show the effects of extensive dissolution and reprecipitation, resulting in many cemented areas in the sample. Intact coccolith shields are uncommon, and the chalky matrix is composed primarily of fragmented coccolith elements and patches of calcium carbonate cement. Overgrowths are present on individual coccolith elements, as well as on the elements of intact coccolith shields. At this stage dissolution and cementation have effectively reduced porosity and created areas of well-lithified chalk at shallow depths of burial ( $435 \mathrm{~m}$ ). In Sample 6 (Fig. 3D), calcite cementation is extensive, producing a mat of small, closely spaced calcite crystals. Overgrowths on the crystal elements in the center of a coccolith shield can be seen on the shield in the lower left corner of the micrograph.

Figure 4 shows the most advanced stages of cementation observed in the chalks sampled at Site 550. Depth of burial was approximately 520 to $580 \mathrm{~m}$, and cementation appears to be pervasive. In Figure 4A dissolution and reprecipitation have produced crystal habits of varying sizes, which are much more abundant than coccolith shields. Overgrowth formation is also apparent (see arrow in Fig. 4C), resulting in coccolith shields characterized by large, blocky crystal elements and highly irregular outlines. In Figure 4B, one area of the sample is relatively uncemented, apparently showing that not all areas alter at the same rate in response to pressure solution. In Figure 4D, cementation is so pervasive that coccolith shields are entirely absent. Many areas of patchy continuous calcite cement were observed in this sample, effectively reducing porosity to less than $1 \%$ in parts of Sample $8(575 \mathrm{~m}$ in depth). In the center-right portion of Figure 4D, one part of a coccolith shield is visible whose crystal elements are severely deformed through dissolution. The shield also appears to be fused to the patchy cement matrix.

At this stage, most of the features associated with mechanical, and particularly chemical, compaction are present in chalk samples buried less than $500 \mathrm{~m}$ deep. The remaining samples are marly chalks buried at greater depths than those just discussed.

Figure 5 shows some of the features observed from Samples 9 and 10 at a burial depth between 588 and $686 \mathrm{~m}$. Chemical compaction is not as advanced in these samples as it is in samples taken higher in the sediment column. In Sample 9, for example, some coccolith shields appear to be welded together (Figs. 5A and B), but generally cement overgrowths are only a minor component of the sample (Fig. 5C). Similarly, in Sample 10 (Fig. $5 \mathrm{D})$, dissolution and overgrowth formation have fused together two coccolith shields, but the relative abundance of chemical compaction in this sample seems to be less than in samples from above $588 \mathrm{~m}$ in depth.

This change in the degree of diagenetic alteration is likely the result of some variation in one or more factors which determine the "diagenetic potential" of these samples, such as average grain size, sorting, floral composition, and clay content. As can be seen in Figure 5, the clay content of Samples 9 and 10 is generally much higher than in the eight samples taken above $588 \mathrm{~m}$ in depth. Moreover, the average grain size, the degree of sorting, and the skeletal composition as described from smear slides change significantly at this depth, where Inoceramus shell fragments and calcareous planktonic and benthonic foraminifers occur. It seems likely, therefore, that changes in these variables, resulting from differences in original depositional conditions (such as continuous influx of terrestrial detritus or occasional input of shelf debris by debris flows) produced a reversal in the overall trend of increasing cementation with increasing depth.

In Figure 6, four micrographs from samples taken deeper than $470 \mathrm{~m}$ were chosen to contrast further the diagenesis of pure and marly chalks. In Sample 8 (Fig. 6A) calcite cementation is present in the form of well-developed crystals and as irregular patches of cement. Near the coccolith shield in the center of the figure, an unusual cement morphology is present, creating a granular welded texture. In Figure 6B, the development of small calcite crystals in response to dissolution and precipitation has formed geodelike features in much of Sample 6. In Sample 9 (Fig. 6C), clay (illite and montmorillonite) totally surrounds a coccolith shield; it may have enhanced diffusional transport of calcium carbonate during pressure solution. Clay effectively fills and clogs all pore space between coccolith fragments, which in turn greatly reduces porosity. Figure $6 \mathrm{D}$ also shows the presence of clay and its position relative to coccolith crystal elements. The clay in this micrograph is arranged in ribbons that surround crystal element borders.

\section{DISCUSSION}

Those features apparently associated with mechanical compaction are predominant in Samples 1, 2, and 3, which were taken at depths of burial ranging from approximately 100 to $300 \mathrm{~m}$. Mechanical compaction resulted primarily in compactional dewatering, coccolith rotation, repacking, grain orientation, and grain fragmentation. Although the effects of early cementation (rounding of crystal element borders) were observed, mechanical compaction was the primary mechanism responsible for porosity reduction.

At depths of burial between 300 and $400 \mathrm{~m}$, both mechanical and chemical compaction features were present. Numerous coccolith crystal elements were observed with rounded borders and irregular outlines. Calcite overgrowths and spot welding between adjacent coccolith fragments were present, indicating an increase in the intensity of chemical compaction (pressure solution and cementation).

At burial depths between 400 and about $570 \mathrm{~m}$, chemical compaction was the predominant mechanism of diagenetic alteration and porosity reduction. Extensive dissolution and precipitation had occurred, creating overgrowths, patchy cement, and areas of cementation characterized by "mats" composed of euhedral calcite crystals. Porosity reduction was the most extensive in this interval, resulting in areas having as low as $1-5 \%$ overall porosity.

At burial depths greater than $570 \mathrm{~m}$, cementation was not as extensive, apparently because of changes in the lithology of the chalk that inhibited progressive lithification with increasing burial depth. Some cementation 

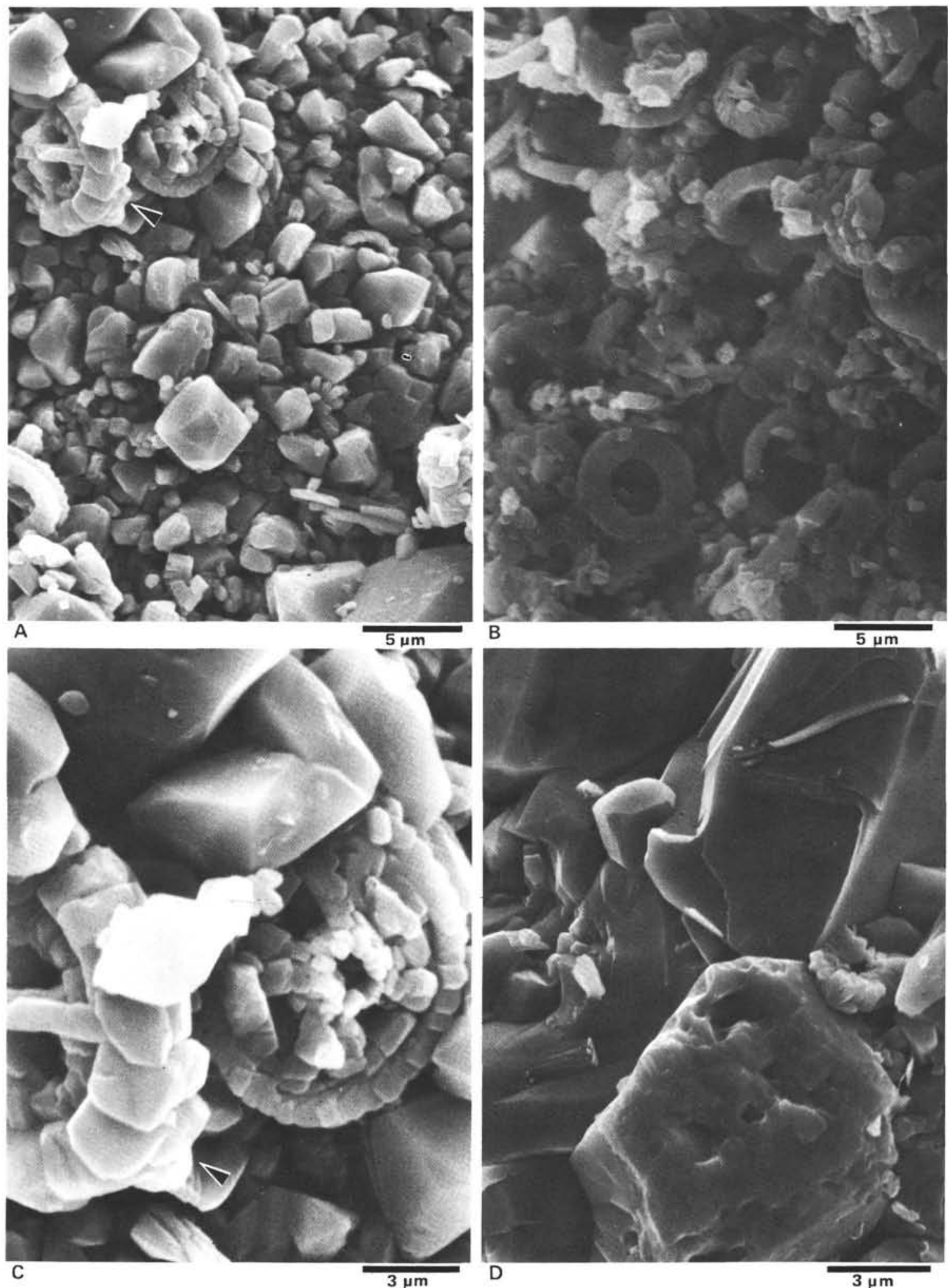

Figure 4. SEM photomicrographs of chalk Samples 7 and 8 showing intensification of overgrowth formation and cementation resulting in very low porosity. A. Overgrowths on two coccoliths from Sample 7, creating irregular blocky outlines, $\times 3000$. Coccoliths are in the upper left corner. Reprecipitation and cementation have resulted in the formation of a mat of calcite cement with well-developed crystal habits. In certain areas of the sample no coccoliths are visible. Depth = 524-534 m. B. Coccoliths from Sample 8 showing the relative absence of overgrowths and cementation in one part of the sample, $\times 3000$. In other areas cementation is extensive, but only mechanical compactive features are present here in any abundance. Depth $=569-579 \mathrm{~m}$. C. Close-up of coccoliths with extensive overgrowths, $\times 7000$. Note the irregular outline of constitutive calcite laths and the surrounding calcite cement composed of well-developed calcite crystals. Depth $=$ $524-534 \mathrm{~m}$. D. Extensive cementation with poor crystal development from another part of Sample 8, $\times 3000$. Porosity effectively reduced to zero. Depth $=569-579 \mathrm{~m}$. 


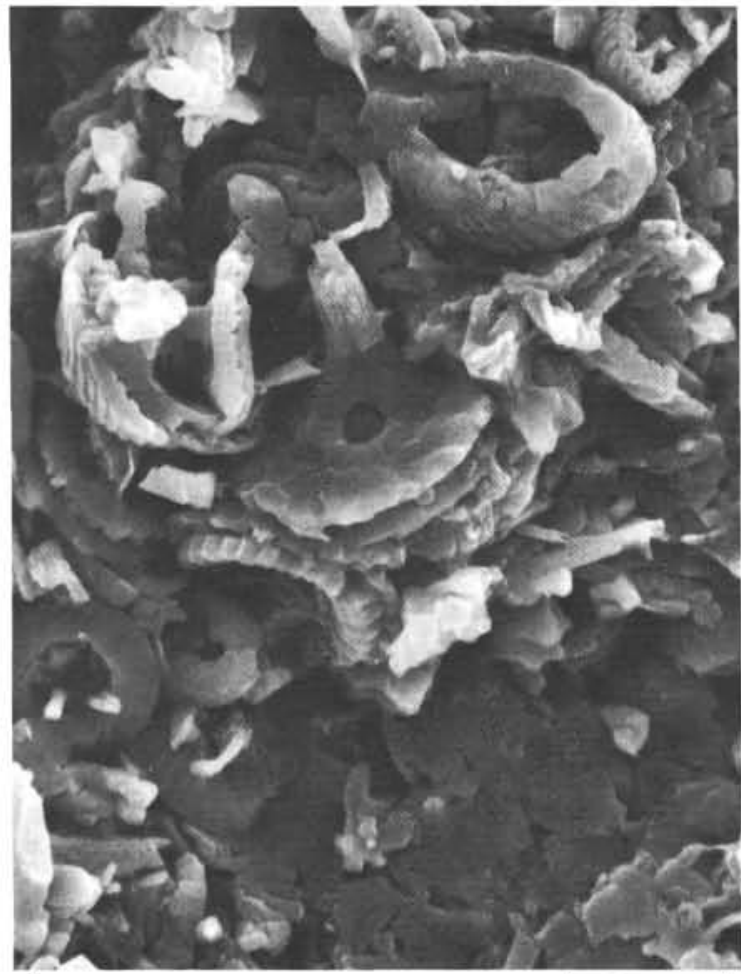

A

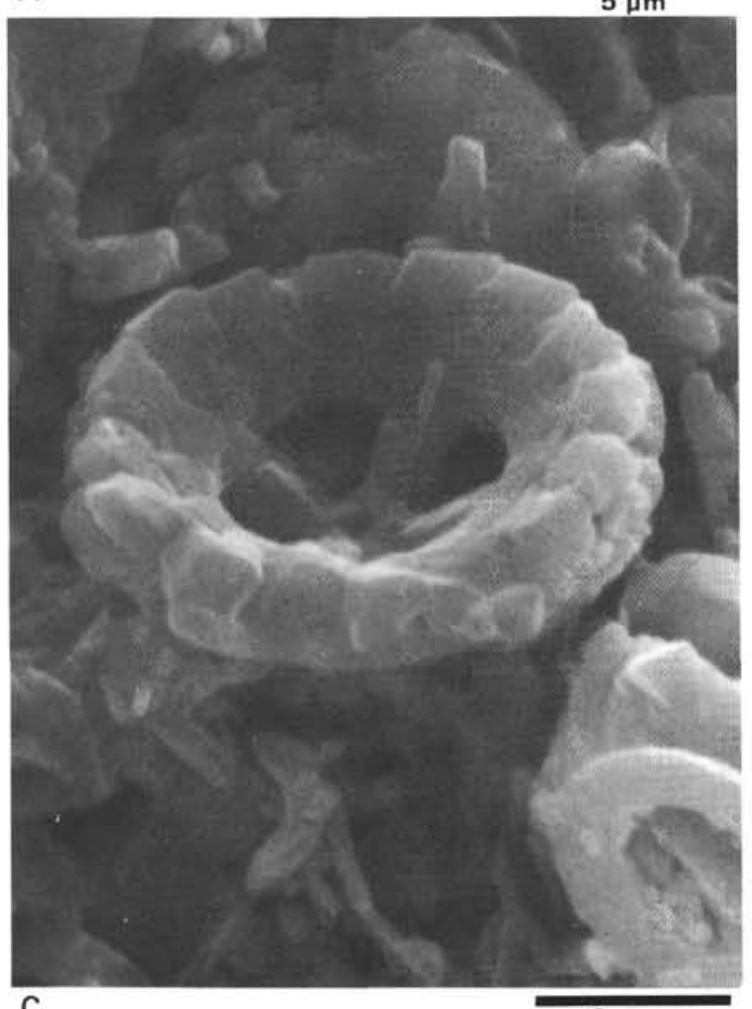

C

$3 \mu \mathrm{m}$

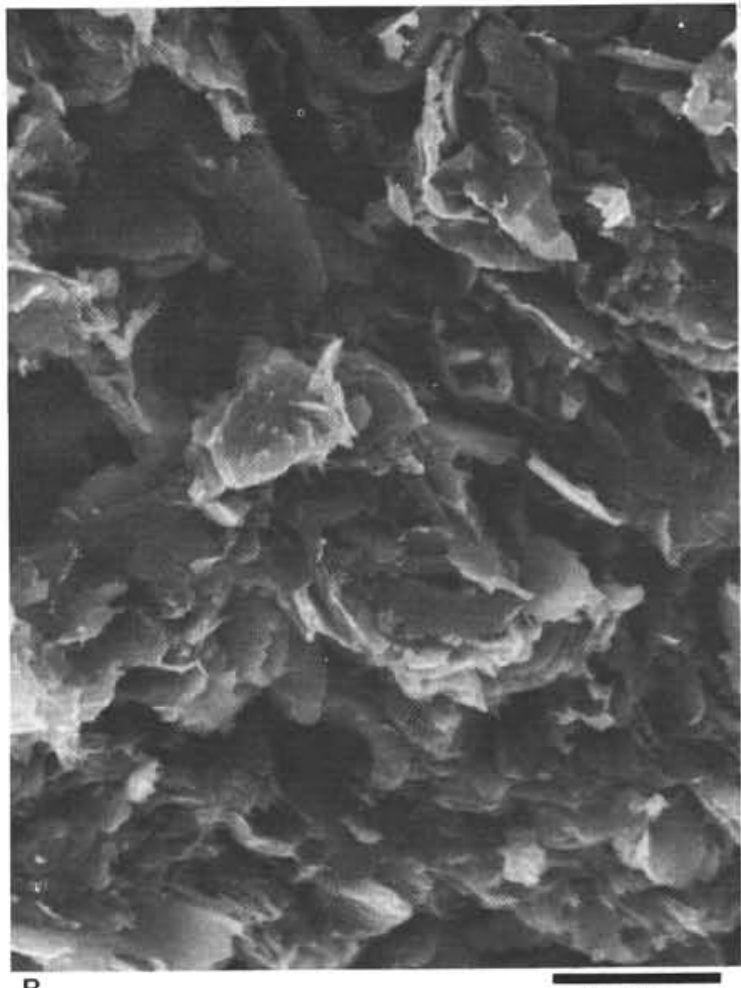

$\mathrm{B}$

$5 \mu \mathrm{m}$

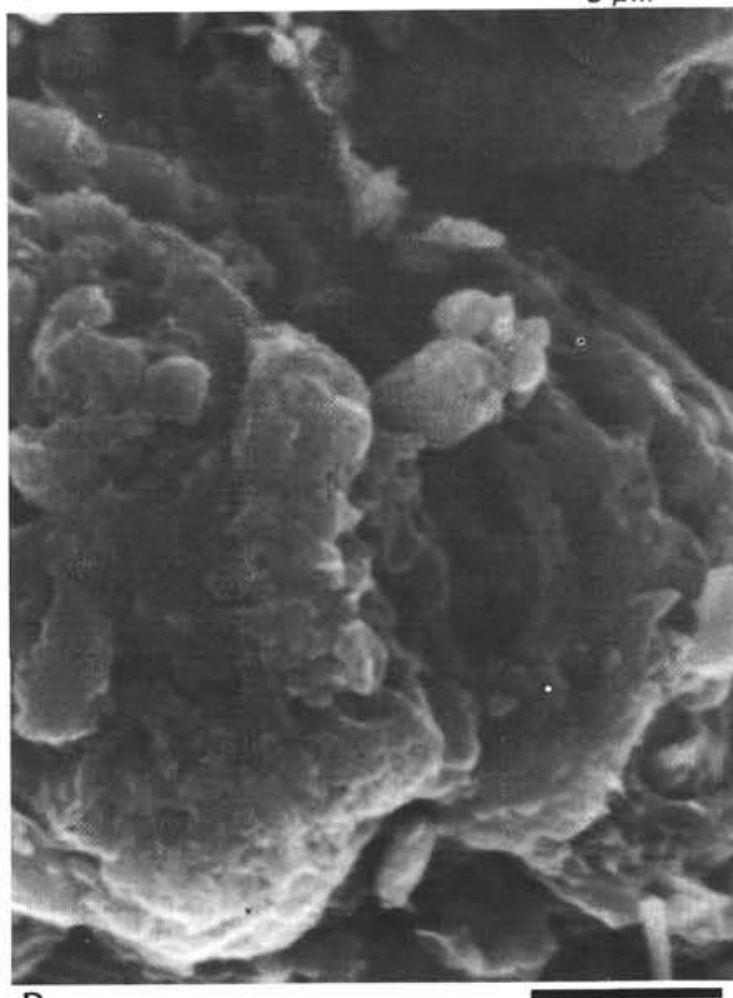

$3 \mu \mathrm{m}$

Figure 5. SEM photomicrographs of chalk Samples 9 and 10 showing less intense chemical compaction features. Porosity is not as reduced as in previous samples and clays are evident. A. Coccoliths from Sample $9, \times 3000$, showing relative absence of overgrowths and cementation as compared with earlier samples. Note oriented fabric of sample, indicating a high degree of mechanical compaction. Depth $=588-598 \mathrm{~m}$. B. Coccoliths and clays from Sample 10, $\times 3000$. Clay is abundant in this sample, completely surrounding coccoliths and coccolith fragments. Some cementation is present. Depth = 680-690 m. C. Close-up of single, undeformed coccolith from Sample 9, $\times 7000$. Surrounding matrix shows the fused, welded texture typical of dissolution. Some of the calcite laths of the coccolith in the picture seem to have minor overgrowths, creating an irregular blocky outline. Depth $=588-598 \mathrm{~m}$. D. Close-up of two coccoliths from Sample 10. Coccoliths appear to be partially fused by pressure solution and lightly covered by cement. Depth $=680-690 \mathrm{~m}$. 

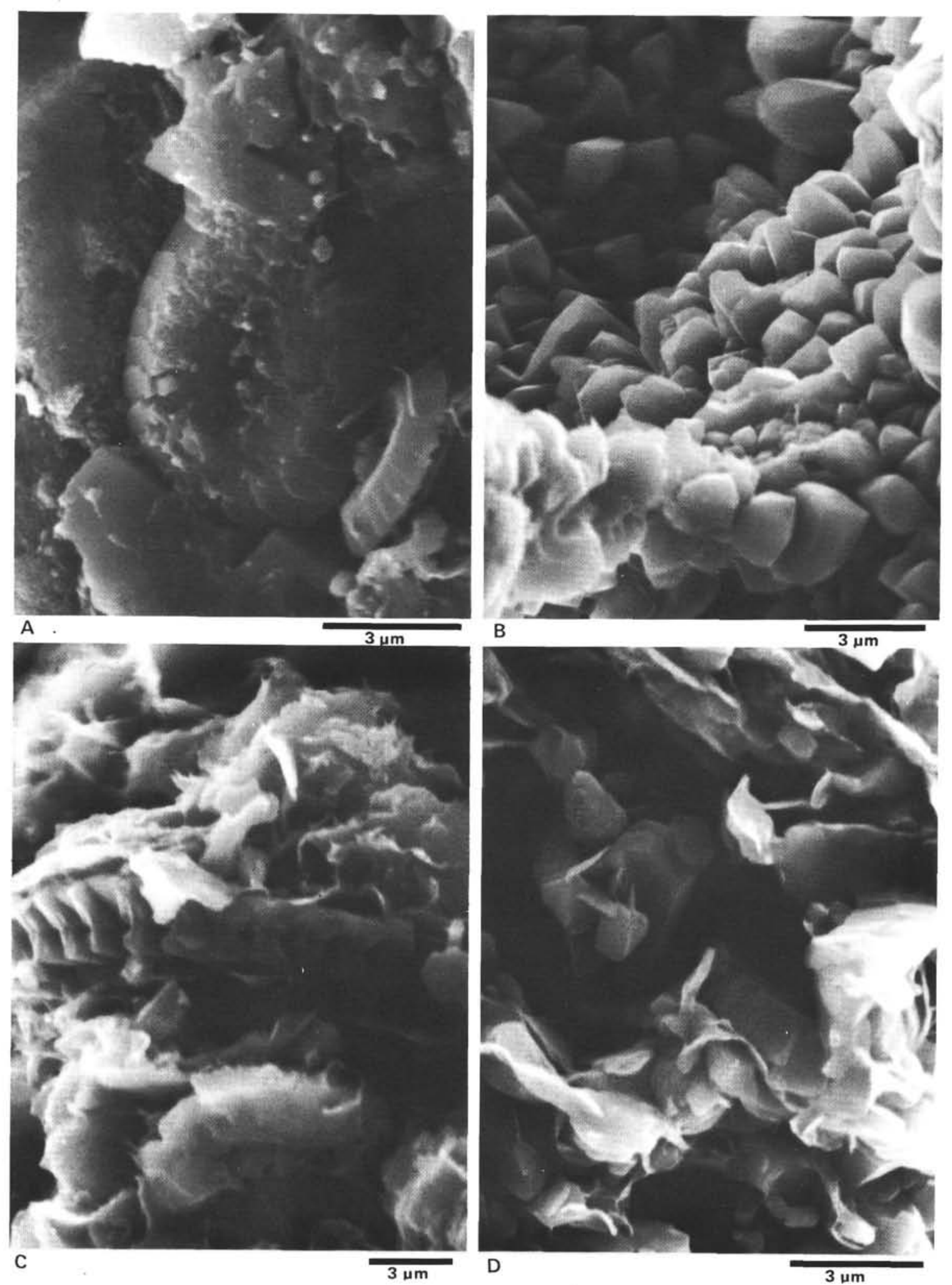

Figure 6. SEM photomicrographs showing contrast between clay-poor (6 and 8 ) and clay-rich ( 9 and 10) samples and their degree of cementation; $\times 7000$. A. Coccoliths from Sample 8 showing advanced cementation resulting in a granular texture. A well-developed calcite crystal is present in the lower part of the micrograph. Porosity is low. Depth $=569-579 \mathrm{~m}$. B. Extensive cementation resulting in well-formed crystals in Sample 6. The morphology of the crystals resembles a geode, and crystals may have grown in a pore or a cavity where a grain, now dissolved, had once been. Depth $=470-480 \mathrm{~m}$. C. Coccolith from Sample 9 showing how clays effectively surround a coccolith and may act as a medium for diffusion of calcium carbonate out of sediment. Depth $=588-598 \mathrm{~m}$. D. Coccolith fragments and clay in Sample 10. Again clays may enhance dissolution but may also lead to diffusion of dissolved calcium carbonate out of sediment. Note high porosity in sample. Depth $=680-690 \mathrm{~m}$. 
was observed, but chemical compaction features were not as prevalent as in previously cited samples. The presence of authigenic or allogenic clay and coarse shell debris was observed and is presumed to have had some effect on the rate of pressure solution.

The diagenetic history of the chalks at Site 550 can thus be summarized by classifying the observed diagenetic features into four diagenetic "facies" as follows:

1. A mechanical compaction facies, with a high to moderate porosity, between 100 and $300 \mathrm{~m}$ below seafloor (BSF);

2. A transitional facies, with both mechanical and chemical compaction features and moderate to low porosity, between 300 and $400 \mathrm{~m} \mathrm{BSF}$;

3. A chemical compaction facies, with very low porosity, between 400 and $570 \mathrm{~m} \mathrm{BSF}$; and

4. A "cement-inhibited" facies with moderate porosity and less pressure solution and reprecipitation than overlying facies, between 570 and 686 BSF.

The "cement-inhibited" facies coincide with an increase in the amount of clay and coarse carbonate debris present in each sample, which may have affected the diffusion of dissolved calcium carbonate through this facies and thus controlled the degree of cementation. The porosity retention in this, the most deeply buried of the facies, might have been the result of overpressurized pore fluids that reduced differential stress at coccolith shield contacts in response to increased hydrostatic pressure. A third possible explanation for the porosity retention at this depth is that pore fluids at this level are more enriched with magnesium than at shallower depths, which could act to retard dissolution and subsequent lithification of the sediment (Scholle, 1977).

In conclusion, through the use of scanning electron microscopy, advanced stages of diagenesis and lithification were observed in chalks at relatively shallow depths of burial (100-700 m). The importance of chemical compaction in particular has been demonstrated, for it has been shown to be the primary mechanism for porosity reduction even at shallow depths. The importance of chalk lithology and pore fluid chemistry in controlling the rate of cementation has been stressed, especially with reference to the relative development rates of advanced diagenetic features.

\section{ACKNOWLEDGMENTS}

The authors wish to thank Dr. Wayne Ahr and Dr. Richard Rezak for their criticisms and constructive comments on this work. Partial support for this research came from the Department of Geology, Texas A\&M University.

\section{REFERENCES}

Adelseck, C. G., Geehan, G. W., and Roth, P. H., 1973. Experimental evidence for the selective dissolution and overgrowth of calcareous nannofossils during diagenesis. Geol. Soc. Am. Bull., 84: 2755-2762.

Bramlette, M. N., and Sullivan, F. R., 1958. Significance of coccolithophorids in calcium carbonate deposition. Geol. Soc. Am. Bull., 69:121-126.

Davies, T. A., and Supko, P. R., 1973. Oceanic sediments and their diagenesis: some examples from deep-sea drilling. J. Sed. Petrol., 43:381-390.

Fischer, A. G., Honjo, S., and Garrison, R. E., 1969. Electron Micrographs of Limestones and Their Nannofossils: Princeton (Princeton Univ. Press).

Kennedy, W. J., and Garrison, R. E., 1975. Morphology and genesis of nodular chalks and hardgrounds in the Upper Cretaceous of Southern England. Sedimentology, 22:311-386.

Manus, R. W., and Cougan, A. H., 1974. Bulk volume reduction and pressure solution derived cement. J. Sed. Petrol., 44:466-471.

Mapstone, N. B., 1975. Diagenetic history of a North Sea chalk. Sedimentology, 22:601-613.

Montadert, L., and Roberts, D., 1977. Northeast Atlantic Passive Continental Margins: Rifting and Subsidence Processes: Wormley, Surrey (Institute of Oceanographic Sciences).

Scholle, P., 1977. Chalk diagenesis and its relation to petroleum exploration: Oil from chalks, a modern miracle? Am. Assoc. Pet. Geol. Bull., 61:982-1009.

Van den Bank, E., and Owen, T., 1981. Ekofisk: First of the giant oil fields in western Europe. Am. Assoc. Pet. Geol. Bull., 65: 2341-2363.

Date of Initial Receipt: December 6, 1982

Date of Acceptance: March 31, 1983 